\title{
EVALUATION OF THE CHEMICAL COMPOSITION AND ALLELOPATHIC POTENTIAL OF ESSENTIAL OILS FROM THREE SPECIES OF ASTERECEAE AGAINST SEED GERMINATION AND SEEDLING VIGOR OF LETTUCE
}

\author{
Cíntia A. S. F. Miranda, Maria das G. Cardoso*, Maria L. M. Carvalho, Marcos de S. Gomes,
} Juliana A. Santiago, Wilder D. Santiago, Maria L. Teixeira, David L. Nelson

Department of Agriculture, Federal University of Lavras (UFLA), Lavras - MG, Brazil cintiafmiranda@yahoo.com.br

Department of Chemistry, Federal University of Lavras (UFLA), Lavras - MG, Brazil mcardoso@dqi.ufla.br*

Department of Agriculture, Federal University of Lavras (UFLA), Lavras - MG, Brazil mlaenemc@dag.ufla.br

Department of Chemistry, Federal University of Lavras (UFLA), Lavras - MG, Brazil marcosopq@yahoo.com.br

Department of Chemistry, Federal University of Lavras (UFLA), Lavras - MG, Brazil juandrade_quimica@yahoo.com.br

Department of Chemistry, Federal University of Lavras (UFLA), Lavras - MG, Brazil wildaoquimica@msn.com

Department of Chemistry, Federal University of Lavras (UFLA), Lavras - MG, Brazil teixeiraml@hotmail.com

Federal University of Vales do Jequitinhonha e Mucuri (UFVJM), Diamantina - MG, Brazil dleenelson@gmail.com

\begin{abstract}
The allelopathic properties of the essential oils have been exploited because they are biodegradable natural compounds that can be used in combination or as prototypes for new bioherbicides. The objectives of this study were to chemically characterize the essential oils from $B$. dracunculifolia, $C$. bonariesis and $T$. diversifolia and to evaluate their allelopathic potential. The essential oils were extracted by hydrodistillation and their chemical compositions were determined by GCMS. Allelopathic activities were determined by methods that evaluate the effects of volatile compounds and direct contact of those compounds on the seed germination and seedling vigor of lettuce. The principal constituents of the essential oil from $B$. dracunculifolia were limonene, trans-nerolidol and $\beta$-pinene; those in the oil from $C$. bonariesis were limonene, trans- $\beta$-ocimene and cis-verbenol (4.4\%); and those in the oil from $T$. diversifolia were $\beta$-pinene, $\alpha$-pinene and limonene. Minor differences in the germination and vigor of lettuce seedlings were observed when they were exposed to the volatile essential oils from the leaves of the three species of the Asteraceae family. However, upon direct contact with these oils, those of $C$. bonariesis presented the greatest allelopathic potential, which was attributed to its higher content of oxygenated monoterpenes.
\end{abstract}

Indexing terms/Keywords:- Volatile oils; Allelopathy; Baccharis dracunculifolia; Conyza bonariesis; Tithonia diversifolia.

Academic Discipline And Sub-Disciplines:- Agricultural Chemistry and Natural Products.

SUBJECT CLASSIFICATION:- Essential oils extracted; chemical composition; bioassays that assess the effect on seed germination and seedling vigor of lettuce.

TYPE (METHOD/APPROACH):- Experimental Analysis.

\section{Council for Innovative Research}

Peer Review Research Publishing System

\section{Journal: Journal of Advances in Chemistry}

Vol 11, No. 6

editorjaconline@gmail.com, www.cirjac.com 


\section{Introduction}

Essential oils are secondary metabolites produced exclusively by plant and are composed of complex mixtures of many compounds. The constituents may be grouped into phenylpropanoids and terpenoids, and, of the latter class, the monoterpene compounds are found in the highest concentration in essential oils [1].

According to Almeida et al. (2010) [2], terpenoid compounds are considered to be important bioactive compounds involved in the defense of plant organisms, which is a reason why essential oils stand out for their allelopathic properties. In addition to this natural property, these volatile compounds do not persist in the soil and contaminate the groundwater and present little or no toxicity to mammals [3], which makes these metabolites an alternative to new synthetic herbicides. Vokou et al. (2003) [4] highlighted the importance of evaluating the allelopathic activity of each essential oil individually because terpenes present in the oils can act independently, synergistically or antagonistically, and this type of interaction between the constituents is not predictable.

Among the plants that produce essential oils, the Asteraceae family is the most numerous systematic group of the Angiosperms, and their chemical compositions and biological activities have been widely explored. Species are very varied in appearance, being composed mainly of small herbs or shrubs comprising about 1100 genera and 25,000 species found mainly in the tropical mountain regions of South America [5].

This study sought to evaluate the chemical composition of the essential oils extracted from fresh leaves of three species of the Asteraceae family -- Baccharis dracunculifolia Conyza bonariesis and Tithonia diversifolia -- and compare their allelopathic potential using bioassays that assess the effect of direct contact with the oil and the effect of contact with the volatile components on seed germination and seedling vigor of lettuce (Lactuca sativa L.) in the laboratory.

\section{Material and Methods}

\subsection{Collection of the plant material}

The Asteraceae plants were collected in the morning, at approximately 8:00 a.m. within the same week, without rainfall, in the month of February 2012. The species collected were properly identified and deposited in the ESAL Herbarium of the Federal University of Lavras (UFLA) and registered under the numbers 26946, 26947 and 26945, respectively. The young leaves (rib and limb) of adult plants of the Baccharis dracunculifolia Conyza bonariesis and Tithonia diversifolia species were collected on the UFLA campus in Lavras, MG, Brazil.

\subsection{Extraction of the essential oils}

The essential oils from the fresh leaves of the test species were extracted by steam distillation during a period of two hours using a modified Clevenger apparatus adapted to a round bottom flask with a capacity of four liters, in accordance with the method described by the Farmacopeia Brasileira (2000) [6]. The hydrolate was centrifuged for five minutes, and the essential oils were separated and stored in amber glass bottles in the refrigerator.

\subsection{Analysis of moisture and yield of the extracted oils}

Five grams of fresh chopped leaves from these plants and $70 \mathrm{~mL}$ of cyclohexane were added to a 250 - $\mathrm{mL}$ round bottom flask attached to a volumetrically graduated collector with a condenser; the mixture was heated at $81 \pm 1{ }^{\circ} \mathrm{C}$ for 2 hours and the volume of water that distilled was measured. The yield of oil extracted from the plant was calculated on a moisture-free basis [7].

\subsection{Identification of the essential oil constituents}

The GC-MS analyses was performed using a Perkin Elmer Autosystem XL gas chromatograph equipped with a fused silica DB-1 column (30 m x $0.25 \mathrm{~mm}$ ID, film thickness $0.25 \mathrm{~m}$; J \& W Scientific Inc.) coupled to a Perkin Elmer Turbomass mass spectrometer (software version 4.1). The oven temperature was programmed from 45 to $175{ }^{\circ} \mathrm{C}$ at $3{ }^{\circ} \mathrm{C} / \mathrm{min}$ and, subsequently, at $15^{\circ} \mathrm{C} / \mathrm{min}$ to $300^{\circ} \mathrm{C}$, where it was held for $10 \mathrm{~min}$. The temperature of the transfer line was $280{ }^{\circ} \mathrm{C}$; the temperature of the ionization chamber was $220^{\circ} \mathrm{C}$; the flow rate of the helium carrier gas was $30 \mathrm{~cm} / \mathrm{s}$; and the split ratio was 1:40.

The identity of the compounds was determined by comparison of their retention indices and mass spectra with those of commercial standards and reference compounds present in oils existing in the laboratory and by comparing the spectra with a library of mass spectra developed in the laboratory of the Centre for Plant Biotechnology of the Faculty of Sciences, University of Lisbon [8].

\subsection{Quantification of the constituents of the essential oils}

The essential oils were analyzed by gas-liquid chromatography on a Perkin Elmer model 8700 gas chromatograph equipped with two flame ionization detectors (FID), a system for data processing and an automatic injector. Two columns of different polarity were installed with the following characteristics: DB-1 fused silica methylsilicone immobilized phase (30 $\mathrm{m} \times 0.25 \mathrm{~mm}$ ID, film thickness $0.25 \mathrm{~m}$; J \& W Scientific Inc.); DB-17HT phenylmethylsilicone immobilized phase (30 $\mathrm{m} \times$ $0.25 \mathrm{~mm}$ id). The oven temperature was programmed from $45^{\circ} \mathrm{C}$ to $175^{\circ} \mathrm{C}$ at $3^{\circ} \mathrm{C} / \mathrm{min}$ and, subsequently, at $15^{\circ} \mathrm{C} / \mathrm{min}$ to $300^{\circ} \mathrm{C}$, where the temperature was maintained for $10 \mathrm{~min}$. The temperatures of the injector and detector were $290 \stackrel{\circ}{\circ}$ and $280^{\circ} \mathrm{C}$, respectively. The flow rate of the hydrogen carrier gas was $30 \mathrm{~cm} / \mathrm{s}$, and the split ratio was $1: 50$. The percentage 
composition of the oils was determined by integration of peak areas without using correction factors. The values given represent the average of two injections.

\subsection{Allelopathic activity of essential oils}

Two bioassays were conducted to evaluate the allelopathic potential of the essential oils. The first test evaluated the effect of the volatile components, and the second assessed the effect of the direct contact of the seeds with the oils on seed germination and seedling vigor of lettuce (cultivar: Regina SF 3500). A 1\% stock solution of each essential oil was prepared by emulsifying the oil with $0.5 \mathrm{~mL}$ Tween 80 in a 1:1 (v/v) ratio and dissolving it in a distilled water emulsion. The 0.1 and $0.01 \% \mathrm{v} / \mathrm{v}$ concentrations were prepared by dilution of the stock solution. A $1.0 \% \mathrm{v} / \mathrm{v}$ solution of Tween 80 in water was used as the control [1]. The solutions were added at the start of the bioassays, and then only distilled water was added, if necessary [9]. In both bioassays, seeds were packed in an acrylic box (gerbox, dimensions $11 \times 11 \times 4 \mathrm{~cm}$ ) with two sheets of sterilized blotting paper as the substrate. Fifty seeds were distributed in each incubator, totaling 200 seeds per treatment. The seeds were kept in a growth chamber at $20 \pm 1^{\circ} \mathrm{C}$ with a photoperiod of 12 hours. In the direct contact method, the blotter paper was soaked with solutions of different concentrations of essential oils in quantities equivalent to 2.5 times its dry weight [10]. To evaluate the effect of the volatile compounds, distilled water was added to the paper substrate in quantities equivalent to 2.5 times the dry weight [10], and $3 \mathrm{~mL}$ of the solutions of the essential oils were placed on two sheets of filter paper affixed to the gerbox cover, thereby avoiding direct contact of the solution with the seeds [9]. Germination was monitored for seven days after the implementation of the test, with daily counts of lettuce seedlings, and the results were expressed as the percentage of normal seedlings [10].

Seed vigor was determined by using the following variables: First Count Germination, which evaluated the germination of normal seedlings on the fourth day after sowing [10]; Germination Speed Index (GSI), calculated according to the index proposed by Maguire (1962) [11]; Medium Root Length and Length of Seedling Shoots on the Seventh Day, conducted with the aid of a millimeter ruler, and the average results were expressed in centimeters [10]; Determination of Dry Matter of Seedlings, performed in an oven at $60^{\circ} \mathrm{C}$ in Kraft paper bags to constant weights. Finally, the seedlings were weighed, and the averages per repetition were determined [12].

\subsection{Statistical Analysis}

The experimental design for both methods was completely randomized in a $4 \times 3$ factorial scheme (concentrations $x$ essential oils), with four replications. The essential oils were compared to one another, because the species are of the same botanical family, as opposed to comparing the different methods, which were not compared because they are known to involve different chemical mechanisms. Significant factors from the F test $(p<0.05)$ were submitted to the Scott-Knott mean test $(5 \%)$ for the determination of the models. The data were analyzed using the Analysis of Variance for Balanced Data statistical program - Sisvar, according to Ferreira (2011) [13].

\section{Results and discussion}

The yields of essential oil obtained from the leaves of Baccharis dracunculifolia, Conyza bonariesis and Tithonia diversifolia were $0.8,0.4$ and $0.2 \%$, respectively. The chemical constituents of these essential oils, their percentages and retention indices are presented in Table 1.

We identified $95.2,97.3$ and $99.7 \%$ of the chemical compounds in the essential oils from fresh leaves of $B$. dracunculifolia, C. bonariesis and T. diversifolia, respectively. Monoterpenes (58.5, 92.2 and $86.3 \%$, respectively) were the most abundant in all the oils, while sesquiterpenoids were found in concentrations of $36.6,5.1$ and $13.4 \%$, respectively.

The principal constituents found in the oil from B. dracunculifolia were limonene (30.9\%), trans-nerolidol (22.4\%) and $\beta$ pinene (14.5\%). However, Massignani et al. (2009) [14] identified nerolidol (23.58\%), germacrene-D (21.54\%) and bicyclogermacrene $(19.24 \%$ ) as the principal components of the essential oil from the leaves of $B$. dracunculifolia collected in the city of Franca, SP, Brazil. Some constituents were found in larger quantities in the oil from C. bonariesis: limonene (56.7\%), trans- $\beta$-ocimene (26.3\%) and cis-verbenol (4.4\%). Barbosa et al. (2005) [15] identified limonene (29.6\%), manool $(13.8 \%)$ and trans-a-bergamotene $(10.3 \%)$ as major components of the leaf oil from $C$. bonariensis collected in Viçosa, MG, Brazil. The essential oil from T. diversifolia contained $\beta$-pinene $(38.3 \%)$, $\alpha$-pinene $(28.6 \%)$ and limonene $(8.8 \%)$ as the principal constituents, while the main compounds found in essential oils extracted from the same species collected in Nigeria and studied by Moronkola et al. (2007) [16] were $\alpha$-pinene (32.9\%), $\beta$-caryophyllene (20.8\%) and D-germacrene (12.6\%). The differences in chemical compositions of the essential oils of the same botanical species are possibly due to the fact that they were collected at different sites and consequently, were submitted to different soil and climatic conditions [17]. 
Table 1. Percentages and retention indices (RI) of the components identified in the essential oils of Baccharis dracunculifolia, Conyza bonariesis and Tithonia diversifolia

\begin{tabular}{|c|c|c|c|c|}
\hline Components & $\mathbf{R I}$ & B. dracunculifolia & C. bonariesis & T. diversifolia \\
\hline Tricyclene & 921 & - & - & $\mathrm{t}$ \\
\hline a-Tujene & 924 & 0.9 & $t$ & $\mathrm{t}$ \\
\hline a-Pinene & 930 & 7.1 & 0.4 & 28.6 \\
\hline Canfene & 938 & $\mathrm{t}$ & 0.2 & 1.0 \\
\hline Sabinene & 958 & $\mathrm{t}$ & 0.4 & 2.1 \\
\hline$\beta$-Pinene & 963 & 14.5 & 0.2 & 38.3 \\
\hline 1.8-Dehydrocineol & 973 & - & $\mathrm{t}$ & - \\
\hline$\beta$-Mircene & 975 & 3.2 & 1.6 & - \\
\hline$\delta$-3-Carene & 1000 & 0.3 & - & - \\
\hline o-Cimene & 1000 & $t$ & - & - \\
\hline$\alpha$-Terpinene & 1002 & - & 0.1 & - \\
\hline$p$-Cimene & 1003 & 0.1 & $\mathrm{t}$ & $\mathrm{t}$ \\
\hline 1.8-Cineol & 1005 & - & 0.4 & - \\
\hline$\beta$-Phelandrene & 1005 & $t$ & 0.4 & 0.4 \\
\hline Limonene & 1009 & 30.9 & 56.7 & 8.8 \\
\hline cis- $\beta$-Ocimene & 1017 & $\mathrm{t}$ & 0.3 & 7.0 \\
\hline Acetofenone & 1017 & $\mathrm{t}$ & - & - \\
\hline trans- $\beta$-Ocimene & 1027 & 0.5 & 26.3 & $\mathrm{t}$ \\
\hline $\mathrm{y}$-Terpinene & 1035 & 0.4 & 0.2 & $\mathrm{t}$ \\
\hline trans-Sabinene hydrate & 1037 & - & $t$ & $\mathrm{t}$ \\
\hline Terpinolene & 1064 & 0.4 & $\mathrm{t}$ & $\mathrm{t}$ \\
\hline Nonanal & 1073 & - & - & $\mathrm{t}$ \\
\hline Linalol & 1074 & 0.3 & $t$ & - \\
\hline Isopentyl isovalerate & 1084 & - & - & $\mathrm{t}$ \\
\hline trans-p-2-Menten-1-ol & 1099 & - & $t$ & - \\
\hline cis-Miroxide & & - & 0.2 & - \\
\hline cis-Verbenol & 1110 & - & 4.4 & - \\
\hline trans-Miroxide & & - & $\mathrm{t}$ & - \\
\hline allo-Ocimene & 1110 & - & - & $\mathrm{t}$ \\
\hline trans-Limonene oxide & 1112 & - & 0.2 & - \\
\hline trans-Verbenol & 1114 & - & - & $\mathrm{t}$ \\
\hline Pinocarvone & 1121 & - & - & $\mathrm{t}$ \\
\hline Borneol & 1134 & - & 0.2 & 0.2 \\
\hline Criptone & 1143 & - & - & $\mathrm{t}$ \\
\hline Terpinen-4-ol & 1148 & 0.1 & 0.2 & $\mathrm{t}$ \\
\hline Mirtenal & 1153 & - & - & $\mathrm{t}$ \\
\hline$\alpha$-Terpineol & 1159 & $t$ & 0.2 & - \\
\hline Mirtenol & 1168 & - & - & $\mathrm{t}$ \\
\hline Carvone & 1210 & - & $\mathrm{t}$ & - \\
\hline
\end{tabular}




\begin{tabular}{|c|c|c|c|c|}
\hline Bornyl acetate & 1265 & - & $\mathrm{t}$ & - \\
\hline Thymol & 1275 & - & - & $\mathrm{t}$ \\
\hline Geranyl formate & 1285 & - & - & $\mathrm{t}$ \\
\hline Carvacrol & 1286 & - & $t$ & $t$ \\
\hline$\delta$-Elemene & 1332 & $\mathrm{t}$ & $\mathrm{t}$ & $\mathrm{t}$ \\
\hline Silfinene & & - & $t$ & - \\
\hline 7-epi-Silfipertol-5-ene & & - & 0.1 & - \\
\hline Modheo-2-ene & & - & $\mathrm{t}$ & - \\
\hline a-Copaene & 1375 & - & - & $\mathrm{t}$ \\
\hline Daucene & 1379 & - & $t$ & - \\
\hline Isodaucene & & - & $\mathrm{t}$ & - \\
\hline$\beta$-Elemeno & 1388 & 0.1 & $\mathrm{t}$ & $\mathrm{t}$ \\
\hline 1.4-Dimetil azuleno & & - & - & $\mathrm{t}$ \\
\hline$\beta$-Caryophylene & 1414 & 1.1 & 0.3 & 3.7 \\
\hline cis- $\alpha$-Bergamotene & & - & 0.5 & - \\
\hline Aromandrene & 1428 & 0.3 & - & - \\
\hline a-Humulene & 1447 & $\mathrm{t}$ & 0.2 & $\mathrm{t}$ \\
\hline trans- $\beta$-Farnesene & 1455 & - & 0.1 & - \\
\hline allo-Aromadendrene & 1456 & - & - & $\mathrm{t}$ \\
\hline trans- $\beta$-Ionone & 1456 & - & - & $\mathrm{t}$ \\
\hline Cabreuva A oxide & 1455 & 0.3 & - & - \\
\hline Cabreuva B oxide & 1463 & 0.7 & - & - \\
\hline Cabreuva C oxide & & 0.0 & - & - \\
\hline Cabreuva D oxide & & 0.3 & - & - \\
\hline Y-Muurolene & 1469 & 0.3 & 0.2 & - \\
\hline Zierene & 1473 & - & - & $\mathrm{t}$ \\
\hline Germacreno-D & 1474 & 1.9 & 0.2 & 0.2 \\
\hline$\beta$-Selinene & 1476 & - & - & $t$ \\
\hline Bicyclogermacrene & 1487 & 2.3 & 1.8 & 1.7 \\
\hline a-Muurolene & 1494 & 0.4 & - & - \\
\hline$\beta$-Bisabolene & 1500 & - & - & $t$ \\
\hline v-Cadinene & 1500 & 1.4 & 0.1 & - \\
\hline$\delta$-Cadinene & 1505 & 1.3 & 0.2 & 0.1 \\
\hline Kessane & 1517 & - & - & 0.1 \\
\hline Isocaryophylene & 1528 & - & - & $\mathrm{t}$ \\
\hline Germacrene-B & 1533 & - & $\mathrm{t}$ & - \\
\hline cis-3-Hexenyl benzoate & 1533 & - & - & $\mathrm{t}$ \\
\hline trans-Nerolidol & 1549 & 22.4 & 0.3 & $t$ \\
\hline Espatulenol & 1551 & 1.6 & 0.3 & 3.9 \\
\hline Germacreno-D-4-ol & 1557 & - & 0.3 & - \\
\hline$\beta$-Caryophylene & 1561 & 0.9 & 0.1 & 2.9 \\
\hline Carotol & & - & $t$ & - \\
\hline
\end{tabular}




\begin{tabular}{lcccc}
\hline Humulene II epoxide & & - & - & $\mathrm{t}$ \\
Viridiflorol & 1569 & 0.1 & - & - \\
Ledol & 1580 & 0.8 & - & - \\
T-Cadinol & 1616 & - & 0.1 & 0.8 \\
epi-a-Cadinol & 1616 & $\mathrm{v}$ & - & - \\
a-Muurolol & 1618 & - & 0.1 & - \\
a-Cadinol & 1626 & 0.4 & 0.4 & - \\
Phytol acetate & 2047 & - & - & $\mathrm{t}$ \\
Diterpene NI & & - & 1.2 & - \\
\% Identification & & 95.2 & 97.3 & 99.7 \\
Grouped components & & & & \\
Monoterpene hydrocarbons & & 58.3 & 86.6 & 86.6 \\
Oxygen-containing monoterpenes & & 0.3 & 5.6 & 0.2 \\
Sesquiterpene hydrocarbons & & 9.1 & 3.4 & 5.8 \\
Oxygen-containing sesquiterpenes & & 27.5 & 1.7 & 7.6 \\
\hline
\end{tabular}

$\mathrm{RI}$, retention index; t, trace $(<0.05 \%)$; NI, not identified.

When the volatile allelopathic effects of the components of the essential oils from the three species of the Asteraceae family were evaluated (Table 2), it was found that an increase in the concentration did not affect the first count germinated seedlings or the final germination, which had mean values of 89 and $94.3 \%$ respectively. There was no statistically significant difference in the effects of these variables on the IGV of the oils, the percentage of dry matter or the measurements of the aerial parts of the plants. However, the effect of the concentrations of each oil on the phytotoxicity was shown to be dose-dependent. In relation to the root length of the seedlings, the effect of different concentrations of the essential oil from $C$. bonariesis did not differ from that of the control, with a mean length of $38.3 \mathrm{~mm}$. However, when the interference of the essential oils from $B$. dracunculifolia and $T$. diversifolia on this variable was evaluated, it was found that the concentration of $1 \%$ caused a decrease in the length to 32.6 and $33.9 \mathrm{~mm}$, respectively.

According to the data described in Table 3, the direct contact with different concentrations of the essential oil from $B$. dracunculifolia did not affect the first germination count or the final number of seedlings germinated. However, the other variables were affected by concentrations of 0.1 and $1 \%$ of oil, which caused significant reductions in the GSI, percentage of dry matter and aerial and root lengths of the seedlings. This behavior can be explained by the delay in the germination of the seeds, especially in the first two days of the experiment, caused by higher concentrations of the oil from $B$. dracunculifolia. This fact justifies the constant value of the variables for the first count and total germination and the dosedependent responses of other variables. Unlike the oil from $B$. dracunculifolia, the oils from $C$. bonariesis and $T$. diversifolia presented dose-dependent allelopathic responses for all the variables. This fact shows that these oils reduced seed germination and seedling vigor throughout the experimental period.

Table 2. Allelopathic volatile effects of components of the essential oils from fresh leaves of the $B$. dracunculifolia, C. bonariesis and T. diversifolia species on seed germination and seedling vigor of lettuce.

$$
\text { EO (\%) v/v } \quad \text { 1st cont. (\%) } \quad \text { Germ. (\%) } \quad \text { GSI } \quad \text { Dry M.(g) } \quad \text { P. aerial (mm) } \quad \text { P. } \operatorname{root}(\mathrm{mm})
$$

\begin{tabular}{ccccccc}
\hline B.dracunculifolia & & & & & & \\
$\mathbf{0}$ & $88 \mathrm{Aa}$ & $94 \mathrm{Aa}$ & $75.8 \mathrm{Aa}$ & $0.0370 \mathrm{Aa}$ & $17.6 \mathrm{Aa}$ & $38.4 \mathrm{Aa}$ \\
$\mathbf{0 . 0 1}$ & $90.5 \mathrm{Aa}$ & $93.5 \mathrm{Aa}$ & $69.5 \mathrm{Aa}$ & $0.0360 \mathrm{Aa}$ & $14.4 \mathrm{Aa}$ & $36.8 \mathrm{Aa}$ \\
$\mathbf{0 . 1}$ & $93 \mathrm{Aa}$ & $97 \mathrm{Aa}$ & $69.2 \mathrm{Ab}$ & $0.0293 \mathrm{Aa}$ & $14.9 \mathrm{Ab}$ & $36.3 \mathrm{Aa}$ \\
$\mathbf{1}$ & $88.5 \mathrm{Aa}$ & $93.5 \mathrm{Aa}$ & $56.0 \mathrm{Ac}$ & $0.0290 \mathrm{Ab}$ & $13.7 \mathrm{Ab}$ & $32.6 \mathrm{Bb}$ \\
C. bonariesis & & & & & & \\
$\mathbf{0}$ & $88.5 \mathrm{Aa}$ & $95 \mathrm{Aa}$ & $75.2 \mathrm{Aa}$ & $0.0370 \mathrm{Aa}$ & $17.1 \mathrm{Aa}$ & $38.3 \mathrm{Aa}$ \\
$\mathbf{0 . 0 1}$ & $85.5 \mathrm{Aa}$ & $91.5 \mathrm{Aa}$ & $74.0 \mathrm{Aa}$ & $0.0370 \mathrm{Aa}$ & $17.1 \mathrm{Aa}$ & $38.3 \mathrm{Aa}$ \\
$\mathbf{0 . 1}$ & $90.5 \mathrm{Aa}$ & $94 \mathrm{Aa}$ & $73.3 \mathrm{Ab}$ & $0.0365 \mathrm{Aa}$ & $16.4 \mathrm{Ab}$ & $38.0 \mathrm{Aa}$ \\
$\mathbf{1}$ & $90 \mathrm{Aa}$ & $95.5 \mathrm{Aa}$ & $64.2 \mathrm{Ac}$ & $0.0346 \mathrm{Ab}$ & $15.0 \mathrm{Ab}$ & $36.4 \mathrm{Aa}$ \\
\cline { 2 - 7 } & & & & & &
\end{tabular}


T. diversifolia

$\begin{array}{ccccccc}\mathbf{0} & 90.5 \mathrm{Aa} & 94 \mathrm{Aa} & 75.5 \mathrm{Aa} & 0.0375 \mathrm{Aa} & 17.0 \mathrm{Aa} & 39.9 \mathrm{Aa} \\ \mathbf{0 . 0 1} & 91 \mathrm{Aa} & 93.5 \mathrm{Aa} & 74.1 \mathrm{Aa} & 0.0378 \mathrm{Aa} & 17.1 \mathrm{Aa} & 38.7 \mathrm{Aa} \\ \mathbf{0 . 1} & 93 \mathrm{Aa} & 95 \mathrm{Aa} & 64.6 \mathrm{Ab} & 0.0345 \mathrm{Aa} & 14.2 \mathrm{Ab} & 36.7 \mathrm{Ab} \\ \mathbf{1} & 89.5 \mathrm{Aa} & 93.5 \mathrm{Aa} & 60.4 \mathrm{Ac} & 0.0340 \mathrm{Ab} & 12.9 \mathrm{Ab} & 33.9 \mathrm{Bc}\end{array}$

$\mathrm{EO}$, concentration of solutions of essential oils; 1st cont., Percentage of seeds germinated on the fourth day of the experiment; Germ., Percentage of seeds germinated on the seventh day of the experiment; GSI, germination speed index; Dry M., average seedling dry mass; P. aerial, average length of the aerial parts of the plants; P. root; average length of seedling roots. For each variable, means followed by the same letter, uppercase for comparison between the essential oils analyzed and lowercase for comparison between concentrations in each essential oil, do not differ significantly at $5 \%$ probability by the Scott-Knott test.

Table 3. Effects of direct contact of the essential oils from fresh leaves of the $B$. dracunculifolia, $C$. bonariesis and T. diversifolia species on seed germination and seedling vigor of lettuce.

\begin{tabular}{|c|c|c|c|c|c|c|}
\hline EO (\%) v/v & 1st cont. (\%) & Germ. (\%) & GSI & Dry M.(g) & P. aerial $(\mathrm{mm})$ & P. root $(\mathrm{mm})$ \\
\hline \multicolumn{7}{|c|}{ B.dracunculifolia } \\
\hline 0 & $91 \mathrm{Aa}$ & $96 \mathrm{Aa}$ & 76.4Aa & $0.0378 \mathrm{Aa}$ & $15.9 \mathrm{Aa}$ & $42.6 \mathrm{Aa}$ \\
\hline 0.01 & $91.5 \mathrm{Aa}$ & $94.5 \mathrm{Aa}$ & 72.9Aa & $0.0375 \mathrm{Aa}$ & 15.8Aa & 41.3Aa \\
\hline 0.1 & $93 \mathrm{Aa}$ & $96 \mathrm{Aa}$ & $44.8 \mathrm{Ab}$ & $0.0300 \mathrm{Ab}$ & $10.5 \mathrm{Ab}$ & $31.5 \mathrm{Ab}$ \\
\hline 1 & $87.5 \mathrm{Aa}$ & $91.5 \mathrm{Aa}$ & $42.9 A c$ & $0.0295 \mathrm{Ab}$ & $10.2 \mathrm{Ab}$ & $29.6 \mathrm{Bc}$ \\
\hline \multicolumn{7}{|l|}{ C. bonariesis } \\
\hline 0 & $87 \mathrm{Aa}$ & $92.5 \mathrm{Aa}$ & $76.5 \mathrm{Aa}$ & $0.0373 \mathrm{Aa}$ & $15.2 \mathrm{Aa}$ & $42.6 \mathrm{Aa}$ \\
\hline 0.01 & $82 \mathrm{Ba}$ & $89 \mathrm{Ba}$ & $49.2 \mathrm{Cb}$ & $0.0338 \mathrm{Bb}$ & $11.0 \mathrm{Bb}$ & $32.1 \mathrm{Cb}$ \\
\hline 0.1 & $76.5 \mathrm{Cb}$ & $90.5 \mathrm{Ba}$ & $39.7 \mathrm{Bc}$ & $0.0303 A c$ & $9.6 A c$ & $26.2 \mathrm{Bc}$ \\
\hline 1 & $69.5 \mathrm{Bc}$ & $74 \mathrm{Bb}$ & 26.4Bd & $0.0218 \mathrm{Bd}$ & 4.2Bd & $13.9 \mathrm{Cd}$ \\
\hline \multicolumn{7}{|l|}{ T. diversifolia } \\
\hline 0 & $94 \mathrm{Aa}$ & $95.5 \mathrm{Aa}$ & 76.4Aa & $0.0370 \mathrm{Aa}$ & 16.4Aa & 41.3Aa \\
\hline 0.01 & 89Aa & $95.5 \mathrm{Aa}$ & $63.2 \mathrm{Bb}$ & $0.0360 \mathrm{Aa}$ & 12.1Bb & $38.4 \mathrm{Bb}$ \\
\hline 0.1 & $83.5 \mathrm{Bb}$ & $89.5 \mathrm{Bb}$ & $47.9 A c$ & $0.0293 \mathrm{Ab}$ & $10.6 \mathrm{Ac}$ & 32.1Ac \\
\hline 1 & $85 A b$ & $90.5 \mathrm{Ab}$ & 44.0Ad & $0.0290 \mathrm{Ab}$ & $10.4 \mathrm{Ac}$ & $32.1 A c$ \\
\hline
\end{tabular}

$\mathrm{EO}$, concentration of solutions of essential oils; 1st cont., Percentage of seeds germinated on the fourth day of the experiment; Germ., Percentage of seeds germinated on the seventh day of the experiment; GSI, germination speed index; Dry M., average seedling dry mass; P. aerial, average length of the aerial parts of the plants; P. root; average length of seedling roots. For each variable, means followed by the same letter, uppercase for comparison between the essential oils analyzed and lowercase for comparison between concentrations in each essential oil, do not differ significantly at $5 \%$ probability by the Scott-Knott test.

A dose-dependent phytotoxicity was observed upon direct contact of the essential oils from Asteraceae plants with the seeds or seedlings, with more pronounced allelopathic effects caused by the use of a $1 \%$ concentration of the essential oils. The oil from $C$. bonariesis had a higher allelopathic efficiency than the essential oils from $B$. dracunculifolia and T.diversifolia with regard to all the variables. It caused significant reductions in the first count from 87 to $69.5 \%$, the total germination from 92.5 to $74 \%$, the GSI from 76.5 to 26.4 , the dry mass from 0.0373 to 0.0218 , the length of the aerial parts from 15.2 to $4.2 \mathrm{~mm}$ and the length of the roots from 42.6 to $13.9 \mathrm{~mm}$.

The greater allelopathic potential presented by the oil from $C$. bonariesis may be associated with the higher content of oxygenated monoterpenes, because the oil contained $5.6 \%$ of these compounds, whereas the oils from $B$. dracunculifolia and T. diversifolia contained 0.3 and $0.2 \%$, respectively. These results corroborate those found by Vokou et al. (2003) [4], who studied the allelopathic activity of 47 hydrocarbons and oxygenated monoterpenes alone and in pairs on seed germination and seedling vigor of lettuce. The authors found that oxygenated monoterpenes have the greatest phytotoxicity. The allelopathic efficiency of the essential oil from Artemisia scopariada, another species of the Asteraceae family, was studied by Kaur et al. (2010) [18]. The authors evaluated the influence of the essential oil by direct contact bioassay on the emergence and growth of the roots and shoots of five weed species: Achyranthes aspera, Cassia occidentalis, Parthenium hysterophorus, Echinochloa crus-galli and Ageratum conyzoides. The authors found a high content of monoterpenes $(55.18 \%$ ), of which those with oxygen totaled $4.99 \%$, similar to the essential oil from $C$. bonariesis in the present study which contains $5.1 \%$ oxygenated monoterpenes. The oil from $A$. scopariada presented 
bioherbicidal properties in concentrations of $2 \%, 4 \%$ and $6 \% \mathrm{v} / \mathrm{v}$, causing changes to the photosynthetic and respiratory metabolism and affecting the growth and physiological processes of some weed species, like the oil from $C$. bonariesis that caused reduction in seed germination and the seedling vigor of lettuce in a concentration of $1 \%$.

\section{Conclusion}

Given the above results, the need to individually analyze the chemical composition and allelopathic potential of essential oils from different species of the same botanical family was confirmed, because essential oils have a unique combination of chemical compounds that directly influence their phytotoxicity. Additionally, the need to examine the allelopathic activity by different bioassays should be emphasized, because the application of the volatile components of the oils caused similar allelopathic effects, unlike the effect of direct contact, which generated different profiles for each individual essential oil that were proportional to the content of oxygenated monoterpenes.

\section{Aknowledgments}

The authors acknowledge the support of the Conselho Nacional de Desenvolvimento Científico e Tecnológico (CNPq), the Coordenação de Aperfeiçoamento de Pessoal de Nível Superior (CAPES), the Fundação de Amparo à Pesquisa do Estado de Minas Gerais (FAPEMIG) and the teacher Ana Cristina da Silva Figueiredo (University of Lisbon) for scientific support, financial and scholarships.

\section{References}

[1] Silva, C.B.; Simionatto, E.; Hess, S.C.; Peres, M.T.L.P.; Simionatto, E.L.; Wisniewski Júnior, A.; Poppi, N.R.; Faccenda, O.; Cândido, A.C.S.; Scalon, S.P.Q. Composição química e atividade alelopática do óleo volátil de Hydrocotyle bonariensis Lam (Araliaceae). Quim. Nova. 2009, 32(9), 2373-2376.

[2] Almeida, L.F.R.; Frei, F.; Mancini, E.; Martino, L.; Feo, V. Phytotoxic Activities of Mediterranean Essential Oils. Molecules. 2010, 15(6), 4309-4323.

[3] Singh, H.P.; Batish, D.R.; Setia, N.; Kohli, R.K. Herbicidal activity of volatile oils from Eucalyptus citriodora against Parthenium hysterophorus. Ann. Appl. Biol. 2005, 146(1), 89-94.

[4] Vokou, D.; Douvli, P.; Blionis, G.J.; Halley, J.M. Effects of monoterpenoids, acting alone or in pairs, on seed germination and subsequent seedling growth. J. Chem. Ecol. 2003, 29(10): 2281-2301.

[5] Verdi, L.G.; Brighente, I.M.C.; Pizzolatti, M.G. Gênero Baccharis (Asteraceae): aspectos químicos, econômicos e biológicos. Quim. Nova. 2005, 28(1): 85-94.

[6] FARMACOPEIA BRASILEIRA. São Paulo: Ateneu. 2000, p.2-7.

[7] Pimentel, F.A.; Cardoso, M.G.; Salgado, A.P.; Aguiar, P.M.; Silva, V.F.; Morais, A.R.; Nelson, D.L. A convenient method for the determination of moisture in aromatic plants. Quim. Nova. 2006, 29(2), 373-375.

[8] Mendes, M.D.; Lima, A.S.; Trindade, H.; Correia, A.I.D.; Barroso, J.G.; Pedro, L.G.; Figueiredo, A.C. ISSR molecular characterization and leaf volatiles analysis of Pittosporum undulatum Vent. naturalized in the Azores archipelago (Portugal). Ind. Crops Prod. 2011, 33(3), 710-719.

[9] Souza Filho, A.P.S.; Guilhon, G.M.S.P.; Zoghbi, M.G.B.; Cunha, R.L. (). Análise comparativa do potencial alelopático do extrato hidroalcoólico e do óleo essencial de folhas de cipó-d'alho (Bignoniaceae). Planta Daninha. 2009, 27(4): 647653.

[10] BRASIL, Ministério da Agricultura e da Reforma Agrária. Regras para Análise de Sementes, Brasília: SNDA/DNDU/CLU. 2009, 399 p.

[11] Maguire, J.D. Speed of germination aid in selection and evaluation for seedling emergence and vigor. Crop Sci. 1962 2(2), 176-177.

[12] Krzyzanowski, F.C.; Vieira, R.D.; França Neto, J.B. Vigor de sementes: conceitos e testes. Londrina: ABRATES. 1999, 218p.

[13] Ferreira, D.F. Sisvar: a computer statistical analysis system. Cien. Agrotecnol. 2011, 35(6), 1039-1042.

[14] Massignan, J.J.; Lemos, M.; Maistro, E.L.; Schaphauser, H.P.; Jorge, R.F.; Sousa, J.P.B.; Bastos, J.K.; Andrade, S.F. Antiulcerogenic Activity of the Essential Oil of Baccharis dracunculifolia on Different Experimental Models in Rats. Phytother. Res. 2009, 23(10), 1355-1360.

[15] Barbosa, L.C.A.; Paula, V.F.; Azevedo, A.S.; Silva, E.A.M.; Nascimento, E.A. Essential oil composition from some plant parts of Conyza bonariensis (L.) Cronquist. Flavour Fragrance J. 2005, 20(1), 39-41.

[16] Moronkola, D.O.; Ogunwande, I.A.; Walker, T.M.; Setzer, W.N.; Oyewole, I.O. Identification of the main volatile compounds in the leaf and flower of Tithonia diversifolia (Hemsl) Gray. J. Nat. Med. 2007, 61(1), 63-66.

[17] Gobbo-Neto L.; Lopes, N.P. Plantas medicinais: fatores de influência no conteúdo de metabólitos secundários. Quim. Nova. 2007, 30(2), 374-381. 
[18] Kaur, S.; Singh, H.P.; Mittal, S.; Batish, D.R.; Kohli, R.K. Phytotoxic effects of volatile oil from Artemisia scoparia against weeds and its possible use as a bioherbicide. Ind. Crops Prod. 2010, 32(1), 54-61. 